Hofmeyr, JW (Hoffie)

University of the Free State

and

Hofmeyr, George S (†) (1945-2009)

Former Director of the National Monuments Council of South Africa

\title{
Establishing a stable society for the sake of ecclesiastical expansion in a frontier capital (King William's Town) in the Eastern Cape: the pensioners and their village between 1855 and 1861
}

\begin{abstract}
For many different reasons, the Eastern Cape area has long been and remains one of the strong focus points of general, political and ecclesiastical historians. In this first article of a series on a frontier capital (King William's Town) in the Eastern Cape, I wish to focus on a unique socio economic aspect of the fabric of the Eastern Cape society in the period between 1855 and 1861 i.e. the establishment of a Pensioners' Village. It also touches on certain aspects of the process of colonization in the Eastern Cape. Eventually all of this had, besides many other influences, also an influence on the further expansion of Christianity in the frontier context of the Eastern Cape. In a next article the focus will therefore be on a discussion and analysis of the expansion of missionary work in this frontier context against the background of the establishment of the Pensioners' Village.
\end{abstract}

\section{INTRODUCTION}

The British settlement of the Eastern Cape region was a long drawn out process, besides that of the local indigenous people, the Xhosa from the north and the Afrikaner settlers from the western Cape. All these settlements not only had a clear socio economic and political effect but it eventually also influenced the ecclesiastical scene. In a series of articles about King William's Town, the capital of British Kaffraria in the Eastern Cape between 1855 and 1866, based primarily on archival research, I wish to reflect on and contribute to a better understanding of this multidimensional context which had a major influence on later developments in South African history. Though the current article is focusing strongly on a socio-economic dimension of the social fibre of the Eastern Cape frontier, the next article will have a stronger historical ecclesiastical focus. Only then will the ecclesiastical interpretation of these settlements be coming stronger to the fore.

Sir George Cathcart was largely only concerned with the proper military control of British Kaffraria. Unlike Sir George Grey, George Cathcart's successor, the latter was against the numerical strengthening of the Province's population through colonization. The only active step that Cathcart took as far as immigration was concerned, was an unsuccessful scheme in 1852 to settle 1500 Swiss riflemen and their families in the Amatola Mountains. ${ }^{1}$ He saw this action as of a purely military nature. It can therefore be clearly stated that before the arrival of the different groups of immigrants like the military pensioners, the British German Legion colonists, the Irish

1 B le Cordeur: Godlonton, p 127 
settlers or the German agricultural settlers, British Kaffraria was little more than a frontier region occupied by the Xhosa and the British military forces.

Sir George Grey saw large-scale European immigration schemes to British Kaffraria as one of the major cornerstones of his policy. He took active measures to encourage it. He was convinced that such immigrants would be of military, economic and cultural benefit to British Kaffraria. By interspersing the Xhosa population with European settlers, Grey hoped to prevent any concerted military uprising of the tribes and at the same time "civilizing" the Xhosa by continuous European contact.

The inhabitants of King William's Town were therefore more concerned about European immigrants and convened a meeting on 30 December 1853 to consider the introduction of convicts into British Kaffraria. The meeting under J H Parker's chairmanship was regarded as a preliminary meeting and was followed by a memorial letter to the High Commissioner, requesting his sanction to hold an official meeting. The idea was to approach the Government officially about the introduction of convicts if such a general meeting expressed itself in favour of it. ${ }^{2}$ According to a reply on 17 January 1854 by Cathcart's private secretary, William Liddle, the High Commissioner was personally not opposed to such a scheme. Because of the countrywide prejudice against convicts at the time, however, it was felt... impossible: "... to entertain such a measure or to recommend it to Her Majesty's Government, and therefore His Excellency is of opinion that to stir in the matter by any public demonstration of opinion at King William's Town would at this moment do more harm than good, and even injure the cause of those who desire." 3

The matter did not, however, rest there and was also raised in the Legislature Assembly later in 1854. ${ }^{4}$ On 4 February 1855 Col Maclean transmitted a further memorial from " ...the principal Inhabitants of King William's Town, and the outposts soliciting the introduction of Immigrants, as also convicts into this Province". ${ }^{5}$ The main aim of the memorialists with the convicts were to supply a cheap labour force for public works and to use them in the defence of the Province. Maclean remarked that he personally was completely against the introduction of convicts, which would cause a general outcry. On the other hand he welcomed the idea of other immigrants which he thought was 'highly desirable' for British Kaffraria. ${ }^{6}$ In his important speech of 15 March 1855 before the Cape parliament, Grey referred to his memorial but expressed himself against any convict scheme. ${ }^{7}$ As an alternative he suggested the introduction of military pensioners.

\section{INTRODUCING MILITARY PENSIONERS}

Even before this Parliamentary speech, the High Commissioner gave indications that he would treat the European colonization of British Kaffraria as a high priority. By the beginning of February 1855 he had already noted the possibility to Maclean of introducing military pensioners to initiate and promote his immigration policy in that territory. The first mention of such a scheme is found in a letter from the Chief Commissioner to the High Commissioner on 3 February in which Maclean acknowledged a note in this regard from the latter. As a result, the Chief Commissioner

2 BK 371: Maclean - W Liddle, Letter 130, 4.1.1854, p 386

3 GH 30/4: W Liddle - Maclean, 17.1.1854, p 71-2

4 G Journal, 31.3.1855 (Undated letter from “An Inhabitant of King William's Town”, inter alia, about John Fairbairn's slanderous attack of 25 August 1854 about the people of British Kaffraria whom he described as " ... wretches and ragamuffin men who have already the blood of convictism amongst them") See also G Journal 23.9.1854 (Letter of protest from “Simper Avon's Eget” from King William's Town).

5 BK 373: Maclean - W Liddle, 4.2.1855, Letter No 199, p 38

6 BK 373: Maclean - W Liddle, 4.2.1855, Letter No 199, p 38-39

7 G Journal, 24.3.1855 
promised to give immediate attention to a suitable site for a Pensioner Village at or near King William's Town. ${ }^{8}$

Soon afterwards, in writing to the Secretary of State on 7 March 1855, Grey suggested that one thousand families of enrolled pensioners should be sent out at once, to be followed gradually by four thousand more families. ${ }^{9}$ Grey was so convinced that his plan would succeed, that he preceded this letter by his already mentioned instructions to Maclean. He first wanted to introduce these pensioners as an experiment in King William's Town where all the facilities were easily available. In a semi-official letter of 10 March to the High Commissioner, Maclean could inform Grey that his requested survey was already under way. ${ }^{10}$

When raising the subject to Parliament on 15 March 1855, Grey pointed out that the object with this pensioner scheme was primarily to ensure peace on the frontier. These immigrants would be able to defend as well as cultivate their property, as had already been done with remarkable success in New Zealand. The main conditions and restrictions which the High Commissioner proposed for the pensioner families were that they had to be married, although there should not be more than five persons per family. The pensioners also had to be medically fit and of a robust frame for the occasional military duties required. They obviously had to be of good character and preference was to be given to agriculturalists and artificers. Grey's idea was further that each applicant would receive a cottage with an acre of land, which would become his property after seven years. ${ }^{11}$ In case off any war these pensioners with their military background and experience would be able to do garrison duty as an organized force and the Governor therefore recommended that such settlements be formed at existing towns. ${ }^{12}$ The far-sighted Grey primarily thought of towns like King William's Town and Alice where there were considerable garrisons, as well as good land under water furrows and where employment was readily available. ${ }^{13}$

In the meanwhile Captain Moodie of the Royal Engineers went ahead with investigations to find the most suitable site in King William's Town. On 24 March 1855 Maclean reported to the High Commissioner that the best site appeared to be on the west bank of the Buffalo River where approximately 130 acres of the best soil could be brought under irrigation. It was estimated that a dam and aqueduct there would not cost more than $£ 250$. "The next site appears to be a continuation of King William's Town's aqueduct, past the mule train Barracks and New Town on the flat, where 175 acres of light sandy soil ... might be well irrigated...in this line there may be added about 14 acres of good soil." 14 The Chief Commissioner stressed that Moody would only be able to complete his survey in the following few days and that the observations were only of a preliminary nature.

Captain Moodie's final sketch and observations were forwarded to Grey together with a letter from Colonel Maclean on 22 April 1855. Moody suggested that seventy prisoners be settled on the west bank and a further three hundred near the race course where an acre of land could be made available to each pensioner. The Chief Commissioner himself felt that the latter figure would be far too many to introduce simultaneously. The soil in the latter locality was also too poor to be useful without labour and expenses. It was, however, preferable to the suggested site on the west bank of the Buffalo as far as advantages in war time and convenience to the pensioners in times of peace were concerned. With manure and sufficient water, the site might

8 GH 8/49: Maclean - Grey, 3.2.1855

9 GM Theal: History of SA from 1795-1872, Vol III, p 192

10 GH 8/49: Maclean - Grey, 10.3.1855

11 J Rutherford: Sir George Grey, p 314 and C Dowsley: Cattle-Killing, p 9

12 G Journal, 24.3.1858 and Resident Magistrate's Records (Miscellaneous Letters from 1853 to 1863)

13 J Rutherford: Sir George Grey, p 314 and G Journal, 9.2.1856 (Editorial)

14 GH 8/49: Maclean - Grey, 24.3.1855 
still be turned to advantage. ${ }^{15}$

Colonel Maclean at the same time made some general remarks about the introduction of pensioners. He suggested to Grey that an important fact to be borne in mind was that these pensioners would not form a mere supplement to an European population but would to a large extent be the nucleus of a new population. To ensure the success of the pensioner scheme in British Kaffraria, the Chief Commissioner therefore recommended the simultaneous introduction of farmers who would be able to employ the pensioners. It was also important to introduce the pensioners in sufficiently reduced numbers, so as to prevent them gradually choking each other's future interests. Maclean in fact felt that the introduction of the seventy pensioner families on the west bank at King William's Town would be ample at first. ${ }^{16}$

Grey thanked the Chief Commissioner for this information and promised to " ... write upon the subject at greater length hereafter". ${ }^{17}$ The pensioner scheme received little further attention for the next five months, pending its official approval by the British Government. At last, in a letter written to Maclean from Dohne on 17 September 1855, the High Commissioner announced the final acceptance of this scheme and also that the first batch of pensioners might be expected as early as November or December 1855. Grey intended the first 500 of these men to be located at King William's Town. His instructions were that rations had to be issued to the pensioners for a few days after their arrival at East London. The men who would not be able to find immediate private employment, could be employed on public works at a rate not exceeding $1 / 6$ per day.

\section{CREATING THE PENSIONERS' VILLAGE}

In the same letter the High Commissioner gave the following important instructions to Maclean, which formed the foundation of Grey's plans for the settlement of pensioners in a Pensioners' Village in King William's Town:

"My wish is, that they should be located at King William's Town, at the back of the New Town in the direction of the Race course, where you should at once cause a Village to be laid out for them ... Every man still in this Village have allotted to him an Erf of 60 feet by 50 feet "' Adjoining this Village a Sub-Urban lot of One acre will be allotted to each pensioner rent free ... Beyond these suburban lots each pensioner may select a country lot of five acres, for which he will be required at once to pay a Quitrent of five Shillings per acre ... So soon as the Village is laid out you should at once cause One hundred Cottages of Twenty feet by Twelve feet each with one Chimney to be erected upon the plan which we have discussed ... No time should be lost in commencing the Water course which will irrigate the land which is to be allotted to the Pensioners ..."18

Grey's selection of the site near the race course and facing the Fort Murray entrance to the town, was influenced by its protection from the river and its size which would also be sufficient for country allotments. He also envisaged that a separate cottage system could be adopted here and that such a Village could be flanked by a gaol, a hospital and a school. ${ }^{19}$

On 18 September 1855 Sir George Grey subsequently gave instructions to reserve ground between the Old and New Town as well as on the other side of the river for future land sales. This was to defray part of the expenses of the pensioner scheme. The High Commissioner also

15 BK 373: Maclean - Grey, 24.3.1855, p 55

16 BK 373: Maclean - Grey, 22.4.1855, p 53-55

17 BK 373: Maclean - Grey, Schedule 190, 28.4.1855

18 BK 437: Grey - Maclean, 17.9.1855, p 254-5

19 BK 405: Maclean - Lt Genl J Jackson, 20.9.1855, p 418 
wanted a street to be laid out between New Town and the proposed Village. ${ }^{20}$

Maclean immediately commenced preparations for the erection of the cottages by trying to obtain tenders. In a letter of 20 September to Lt-Gen Jackson, Commander of Forces in Grahamstown, the Chief Commissioner reported that he had been as yet unsuccessful in getting reasonable tenders. ${ }^{21} \mathrm{He}$ therefore requested the assistance and a few handymen from the military to enable him to commence the Village. ${ }^{22}$ Lt Gen Jackson kindly granted a military party of no less than 80 rank and file of the $45^{\text {th }}$ Regiment. In addition, a gang of Black labourers were to extend the water course. Maclean was satisfied that these measures would enable him to start work as soon as the weather had settled. ${ }^{23}$

Lieutenant George Pomeroy Colley, at that time assistant surveyor of the $2^{\text {nd }}$ Queen's Regiment and not yet twenty years old was appointed to take charge of the whole project. It was Colley's tragic death twenty-six years later as commander of the British Forces in the battle of Amajuba during the first Anglo-Boer War that gave him a special place in South African history. Colley was stationed at Middledrift at the time and the floods caused by torrential rains only temporarily prevented him from going to King William's Town. When he received news of how anxious the Chief Commissioner was to commence with the cottages, Colley waded through a full river with his pony and arrived at his destination the same night.

In a letter addressed to his brother and dated 3 October 1855, Colley remarked as follows about his important work: "I have now regularly begun work. I have drawn out the plan, also sections and plans for the houses, and made estimates ... It is no joking having to build 100 houses of brick and stone at a moment's notice, when the only artificers are to be found among the troops, and I believe the Governor expects it to be done within two months ... A captain, subaltern and 100 men of the $45^{\text {th }} \ldots$ and 200 Fingoes ${ }^{24}$ under some police-officers, have been placed at my disposal; and I have also an almost unlimited command of money. Should this Village succeed, other will be formed on the same plan." 25

It was evident from the beginning that the construction of the cottages was not possible without the assistance of the military authorities. In this regard Maclean pointed out that not a single mason was available among the civil population of King William's Town. This want of skilled masons and carpenters was as a result of various other local building projects which were then under construction, including the Wesleyan Chapel. ${ }^{26}$ The Chief Commissioner's subsequent request of 9 October for more military bricklayers and masons was once again sympathetically received by Lt-Gen Jackson. He immediately ordered every artisan of the $45^{\text {th }}$ Regiment to be made available for the Pensioners' Village, as well as those available in the $2^{\text {nd }}$ and $12^{\text {th }}$ Regiments.

Lt Colley's completed plans of the layout of the ground ${ }^{27}$ and the design of the cottages were dated 10 October $1855 .{ }^{28}$ He gave a detailed description of these plans in a letter to Col Maclean on 25 October. Colley proposed that each house should contain two families, with each family

20 GH 30/4: Grey - Maclean, 18.9.1855, p 145

21 The tenders received were for $£ 60$ and $£ 70$ per cottage respectively (GH 8/49: Maclean - Grey 30.9.1855)

22 BK 405: Maclean - Jackson, 20.9.1855, p 418

23 GH 8/49: Maclean - Grey, 30.9.1855

24 Very little use was in fact made of African labour on this project

25 Butler: Life of Colley, p 26

26 G Journal, 29.9.1855

27 Both the building plots and the acre holdings were laid out in blocks or on a grid system which was by then generally accepted in South African town planning.

28 M1/2591 (Cape Archives): Plan of the Pensioners' Village at King William's Town, signed by G Colley, 10.10.1877 (Enclosure 1 to Despatch 3, Grey - W Molesworth, 17.1.1856 
having two rooms - one of twelve feet by twelve feet and the other twelve feet by eight feet. ${ }^{29}$ In his plans Colley showed these extremely small houses as thatched, but mentioned that if thatch could not be obtained in sufficient quantities, they would be roofed with boards, covered with painted canvass. The cottages were to be built of brick on a stone foundation and with a veranda in front.

The plan also showed two front doors, leading to each of the semi-detached cottages. Each separate cottage would have one front window with three horizontal and three vertical rows of panes, as well as a back window. A hearth for each cottage is shown on both sides of the dividing wall, forming one central chimney. The foundations for the walls were two feet by one foot with the walls nine inches thick and seven feet six inches high. ${ }^{30}$ Captain F Grantham, Colley's successor on this project, gave slightly varying measurements in his undated plan of the cottages, suggesting that Colley's plans might have been slightly adopted later. ${ }^{31}$

Lt Colley further recommended that the outer side of the building lots be enclosed by a loopholed wall for defensive purposes. The only available points were the ends of the streets, which could be flanked by a schoolhouse, a hospital, a gaol or small storehouses. He also proposed a cattle kraal and earmarked the square in the centre, measuring 210 square feet, as a parade ground and point of assembly. Colley further made provision for the possible extension of the Village on the East London side, retaining its 'regularity' and means of defence. The ground lying between the western boundaries of the proposed Village and the Buffalo River was to be divided up into one acre lots. ${ }^{32}$ The latter area was not yet surveyed. The Pensioners' Village itself was, however surveyed by then and the houses marked out.

Although these proposals by Colley were only submitted to the High Commissioner in a letter by Maclean on 30 October 1855 and finally approved thereafter, the actual building activities had already commenced towards the middle of October. By then the working party of the $45^{\text {th }}$ Regiment had been available for some time. Work would certainly have started even earlier, but the inclement weather made this impossible. On 9 October Maclean still reported that the heavy rains prevented these men to encamp.

It is evident that once the weather improved, everyone realized the great urgency of erecting the pensioners' cottages as soon as humanly possible. By 25 October several foundations had been completed and 93 men from the $2^{\text {nd }}, 12^{\text {th }}$ and $45^{\text {th }}$ Regiments were at work. Of these men, 28 were artificers, 56 labourers and 9 non-commissioned officers superintending the works. ${ }^{33}$

Large quantities of building materials soon started to arrive, as is evident from the cash book entries and auditors' books for this period. On 2 November 1855, for example an amount of f86-6-4 was paid out to Henry Whithead, a sawyer, delivering 10358 feet of wood for plank and quartering. The subsequent entries were for varying items such as thatch, loads of poles ${ }^{34}$, charcoal for the blacksmiths, lime, firewood for burning bricks, etc. Frequent references also relate to large numbers of wagons used for transporting the building materials.

Many of these were transporting wood from the nearby forests. Although most of the suppliers of these materials were private contractors, there was initially a great deal of acrimonious feeling among the local traders who felt that their tenders had not been properly

29 BK 377: Colley - Maclean, 25.10.1855

30 M1/2591 (Cape Archives): Plan of the Pensioners' Village at King William's Town (Enclosure 1 to

Despatch 3, Grey - W Molesworth, 17.1.1856)

31 Plan and Section of Military Pensioners Cottages at King William's Town. Unnumbered and housed until recently in the Grey Collection, Auckland, New Zealand. Now housed in the SA Library, Cape Town.

32 BK 377: Colley - Maclean, 25.10.1855 (Grey forwarded this information in a Despatch of 17.1.1856 to

Sir William Molesworth)

33 BK 377: Colley - Maclean, 25.10.1855

34 These poles were essential for the construction of the wattle-and-daub cottages. 
considered before approaching the military authorities. ${ }^{35}$

From all the accounts it appears that the construction of the pensioners' cottages was progressing very well by the beginning of November. Col Maclean reported this rapid progress to Sir George Grey on 3 November and mentioned that the working party was under the command of an excellent officer by the name of Capt Grantham ${ }^{36}$ of the $45^{\text {th }}$ Regiment. ${ }^{37}$ Colley was still in overall control of the project. Grantham was optimistic that the building costs would not exceed $£ 25$ per cottage, but Colley estimated an average cost of $£ 32$ on November 1855 . This meant a total cost of $£ 3200$ for the whole project, including labour. ${ }^{38}$ This figure was approved by Maclean. ${ }^{39}$ Large quantities of material continued to arrive in December 1855. On 1 December, for instance, $\mathbf{f 8 5}$ was paid to Johan Venables for 50 loads of poles. A month later he was again remunerated for 27 loads of poles. By 11 December it was reported that the amount expended had totalled $£ 799-12-6$, of which $£ 502-19-8$ was for material and tools. This included $£ 186-3-$ 11 for planks and quartering, f27-10-0 for firewood and £103-0-9 for tools. ${ }^{40}$ By December there were one captain, two subalterns, four sergeants, seven corporals, thirty-six artificers and ninety-two privates employed on the construction of the Pensioners' Village. Fourteen cottages had already been roofed of which three were thatched. The stone foundations for an additional fourteen cottages had been laid and were ready for the brickwork. It was estimated that between 30000 and 40000 burnt brick were ready for use. ${ }^{41}$

Soon afterwards, on 15 December 1855, Lt Collley's duties as officer in charge of the Pensioners' Village ceased and went over to Capt Grantham. This meant that the latter then had to perform the duties of engineer, in addition to the general superintendence of the work. The construction work on the cottages was now gaining momentum and by 31 December a total of £1471-18-1 had been spent. Thatch started to arrive in large quantities which was an indication of the advanced stage of the project.

Despite all the active preparations for accommodating the pensioners in King William's Town, the general atmosphere of expectancy and excitement in connection with the arrival of these new immigrants gradually gave way to disappointment. The Kaffrarian correspondent of the Grahamstown Journal remarked early in February 1856 on the complete silence concerning the pensioners and wondered whether the scheme had already failed. ${ }^{42}$ It was generally expected that the pensioners would arrive in the ship 'Penelope' during February, but nothing happened. ${ }^{43}$

In Sir George Grey's opening speech he made no secret of his disappointment in the failure of this scheme. ${ }^{44} \mathrm{He}$ announced that with the first call being made in England for candidates it was found that probably not more than ninety pensioners would come. The Home Government

35 G Journal, 10.11.1855 (Communication from King William's Town, 6.11.1855)

36 Capt Grantham and his regiment were also largely responsible for building the Native Hospital, commencing this project immediately after the completion of the Pensioners' cottages.

37 GH 8/49: Maclean - Grey, 3.11.1855

38 In a subsequent undated statement of expenditure by Capt Grantham, he gave the figure of £10-11-6 as labourers' wages for each double cottage and £37-6-2 for materials which included 16000 bricks, 5000 bundles of thatch, 48 glass panes, 7 muids of lime and 2 loads of poles and laths. Document attached to plan of Pensioners' Village in the Grey collection, SA Public Library.

39 BK 93: Estimate of Probable Expenses of One Hundred Pensioner Houses ... p 2

40 BK 93: Estimate of Expenses of One Hundred Pensioner Houses, p 2

41 BK 93: Military Pensioners' Cottages: Number of officers and men employed and amount expended to date.

42 G Journal, 16.2.1856

43 G Journal, 23.2.1856 (Editorial)

44 Lord John Russell, British Secretary for Colonies, in a despatch to Grey on 3 June 1855 was already pessimistic about the possibility of substantial numbers emigrating to British Kaffraria - G Journal, 23.2.56 (Editorial) 
therefore dropped the whole scheme " ... informing the pensioners who had offered to come out that their services would not be required". ${ }^{45}$ Grey then strongly recommended to Parliament that those pensioners who had volunteered ${ }^{46}$, be sent to the frontier with their families. He firmly believed that if one detachment came out, other volunteers would follow as news of the success and comfort of the first group reached England. ${ }^{47}$ The Editor of the Grahamstown Journal stated on 29 March that Grey's announcement would be received with universal regret on the Border. The editor put much of the blame for the failure of this scheme on the United Service Gazette which published several articles advising pensioners against immigrating to South Africa. ${ }^{48}$ In spite of the High Commissioner's sanguine hopes his dream was never to be realized to bring out a detachment of pensioners to King William's Town. A substantial number of families was nevertheless still to settle individually in the Kaffrarian capital as pensioned soldiers from England, apart from similar pensioners from the Cape Colony and British Kaffraria itself.

In the meantime the construction of the pensioner cottages was still making good progress. Although the military working party - especially the artisans - was in great demand elsewhere, the Commander of the Forces agreed on 3 May 1856 that the services of Capt Grantham and his party could be retained on this project as long as possible. ${ }^{49}$ By the middle of 1856 the Pensioners' Village was nearing completion. On 14 July a payment was made for the supply of gum trees for the beautification of the Village, which is an indication that the project was in its final stages. By October the last accounts in connection with the construction of the cottages were settled. It is surprising, however, that none of the contemporary sources refer to the actual date of completion of this large-scale project. The pensioners' cottages were bounded by the present streets known as Alexandra Road (formerly Fort Albany Road), Ayliff Street, and Buffalo Street. ${ }^{50}$

Although it was originally planned to erect 100 cottages, the final number was only 96. This was probably as a result of discarding with the only four single cottages in the Village, i.e. Numbers 1, 50, 51 and 100 on Colley's original plan. ${ }^{51}$ The problem remained to allocate these 96 cottages for alternative public purposes. The original aim of the cottages was still borne in mind and pensioners were encouraged to settle there. Even before the construction of the Pensioners' Village, King William's Town was popular as a place of retirement for invalided and ordinary soldiers, white and coloured alike. In May 1854, for example, the pensioners of the Cape Mounted Riflemen applied to the local magistrate to draw their pensions in town. ${ }^{52}$

The main influx of pensioners arrived in the Kaffrarian capital from 1856 although then not on an organized basis as Grey had originally visualized. This included Hottentots but there is no evidence that they were ever housed in the Pensioners' Village. One of the first pensioners to arrive was George Beasley, late Sergeant Major of the $77^{\text {th }}$ Regiment, who had been strongly recommended by the High Commissioner himself. ${ }^{53}$ Beasley later proved a valuable immigrant

45 Grey's Parliamentary Speech as fully reported in the SA Commercial Advertiser and Cape Town Mail, 15.3.1856

46 Sir William Molesworth mentioned a total of 107 volunteers in a despatch of 12.8 .1855

47 SA Commercial Advertiser and Cape Town Mail, 15.3.1856 (Grey's Parliamentary Speech)

48 G Journal, 29.3.1856 (Editorial)

49 GH 36/1: E Smyth - Capt Robinson (Military Secretary, Cape Town), 3.5.1856, p 340

50 J Bateman: A Hundred Years of Medical Service, p 5

51 M1/2591 (Cape Archives): Plan of the Pensioners' Village at King William's Town, signed by G Colley

(Enclosure 1 to Despatch 3, Grey - W Molesworth, 17.1.1856)

52 CO 634: Maclean - Acting Government Secretary, 4.5.1854 (In another case a further ten pensioners of the Cape Mounted Riflemen who were discharged on 7 March 1857, decided to settle in King William's Town).

53 GH 30/4: Capt S Robinson (Asst Military Secretary) - Maclean, 5.6.1856 
as a superintendent of public works. Applications to join an enrolled pensioner force during the eighteen-fifties were received from far and wide. The number of pensioner families in the Pensioners' Village, however, seldom exceeded forty.

A setback for these pensioners was the cancellation of one of the original privileges that each family would receive i.e. an additional acre of land, apart from his building plot. Sir George Grey explained in a letter to Col Maclean on 29 January 1858 that this decision was mainly influenced by the fact that the value of land in the neighbourhood of King William's Town had already increased. There was also no further intention from authorities to locate pensioners on an organized scale near King William's Town. ${ }^{54}$ Those prospective pensioners would therefore only receive a building plot with a cottage. Three days later, however, the High Commissioner again made a concession to the pensioners by announcing that the cottage of a deceased pensioner would thereafter revert to his family in accordance with the Colonial law of inheritance. ${ }^{55}$ This concession eventually led to fewer pensioners settling in King William's Town itself.

The small pieces of land in the Pensioners' Village caused further representations to be made to the High Commissioner. During 1858 Grey therefore approved the extension of an additional piece of land behind each cottage. ${ }^{56}$ On December 1858 it was subsequently reported in the local press that the men "...are now busily engaged in enclosing their increased privilege". ${ }^{57}$ In April 1859 Sir George Grey made a further allowance as a consolation to pensioners who had been deprived since 1858 of receiving an additional acre of land. He agreed that each of these families could then receive an extra building lot among those erven that were about to be laid out as an extension of the Pensioners' Village. ${ }^{58}$

After the completion of the survey work, Bryant was in a position to point the additional lots to the pensioners on 14 December 1859. A total of 27 plots were involved. ${ }^{59}$ The arrangements were so satisfactory to those involved that some of them held a convivial meeting on the following evening. On this occasion the health of the Queen, the High Commissioner, the Chief Commissioner and the Magistrate were drunk with the greatest enthusiasm. ${ }^{60}$

\section{THE DECLINE OF THE PENSIONERS' VILLAGE}

By 1859 the enthusiasm of the authorities for the pensioners had, however, started to decline. In April 1859 there were thirty-four families in possession of cottages - fourteen of whom also had an acre of land. Colonel Maclean recommended to the High Commissioner on 20 April 1859 that the number of pensioner families in the Village be limited to forty. As motivation he stated that such "... great advantages one at present offered to discharged Soldiers of good character in the acquisition of land, and so many of them have already obtained building lots in the German Village King William's Town, that I conceive that the Govt is in no ways bound to offer any other inducement to this Class of Settlers. The town has moreover now attained a sufficient growth and population to be independent of such support, while the Pensioners now in occupation of Cottages is not generally such as to make it desirable to increase their number - no fewer than four having been ejected in one month for repeated drunken and disorderly conduct." 61 There

54 BK 57: Grey - Maclean, 29.1.1858

55 BK 57: Grey -- Maclean, 1.2.1858

56 BK 386: Maclean - Bryant, 17.12.1858, p 18

57 K Gazette, 18.12.1858 (Notes of the Week)

58 BK 386: Maclean - Taylor, 20.4.1859, p 196

59 BK 3: Bryant - Maclean, 14.12.1859 (At that time all 40 cottages earmarked for pensioners were occupied).

60 K Gazette, 17.12.1859. See also K Gazette, Extra, 20.12.1859

61 BK 373: Maclean - F Travers (Secretary to Grey), 20.4.1859, p 276 
were regular references to such cases of drunkenness among the pensioners in streets and other public places. At that stage the total number of pensioners with their families who resided in King William's Town was estimated at 160.

Another important use for these cottages was originally found when the Native Hospital was established in 1856. From April 1856 eighteen of these cottages were converted to form a temporary hospital. This figure rose to twenty-three in May 1858, when it was stated that the temporary hospital would soon have twenty-six cottages ${ }^{62}$ at its disposal. ${ }^{63}$

A third use for the cottages was that of public offices. In 1857 it was decided to move most of these offices from the Old Town to the Village, which was probably mainly for economic reasons. This step was openly criticized by the public because of the Pensioners' Village inconvenient position, compared to the formal central position of the offices. In December 1857 Maclean gave permission to the Civil Engineer for making the necessary alterations to the nine cottages required. ${ }^{64}$ By May 1858 the number of cottages used for public offices had increased to fourteen. ${ }^{65}$

Yet another functional use of these houses was as accommodation for married soldiers. Lt Colley himself hired a double cottage and in April 1857 unsuccessfully applied for permission to buy it. ${ }^{66}$ By the middle of 1858 there were twenty-five cottages occupied by soldiers and an additional ten cottages in temporary military occupation. This included the use of a double cottage as a German military store. ${ }^{67}$ Immediately after the arrival of the British German Legion, a number of these houses were put at the temporary disposal of the officers of the Corps. Other temporary uses included the accommodation of the Irish immigrants before being placed out with local families or being sent to Grahamstown.

The occupation figures for the Pensioners' Village continued to fluctuate throughout the period under consideration. An increasing number of ordinary local inhabitants also started to occupy the cottages. This was especially so after the completion of the Native Hospital in 1859 and the removal of the public offices in 1861, with the consequent vacating of many of these buildings.

In the meantime new developments and local needs had also necessitated the extension of the original Pensioners' Village. A major difference, however, was that no further Village construction on an organized scale was undertaken by the Kaffraria Government. It seems that the idea for this expansion had originated with Dr Fitz Gerald. In a letter of 15 July 1856 he already envisaged an extensive piece of ground being set aside as endowments for the Native Hospital and School in King William's Town. ${ }^{68}$ Although there were rumours in October 1856 of a survey to extend the Pensioners' Village ${ }^{69}$, nothing further happened until 1858 . By then the necessity of making additional building plots available had been much increased by the arrival of the British German Legion in 1857 and the German immigrants of 1858.

It was towards the end of 1858 that the High Commissioner eventually approved in principle that additional rows of plots be laid out, so as to complete the squares suggested by the form of the Pensioners' Village. Maclean subsequently asked Bryant's opinion on the matter in a

62 BK 379: Maclean - Grey, Schedule 82, 27.5.1858

63 The actual use of these cottages for hospitalisation is dealt with in the chapter on Health and

Hospitalisation.

64 BK 406: Maclean - Pilkington, 14.12.1857, p 375

65 BK 379: Maclean - Grey, Schedule 82, 27.5.1858

66 BK 378: Maclean - Grey, Schedule 430, 13.4.1857

67 BK 379: Maclean - Grey, Schedule 82, 27.5.1858. (At that stage 22 cottages were occupied by

pensioners).

68 BK 377: Maclean - Grey, Schedule 355, 27.11.1856

69 K Gazette, 16.10 .1856

402 Deel 52, NOMMERS 3 \& 4, SEPTEMBER \& DESEMBER 2011 
letter of 17 December, enquiring at the same time how long a survey and lay-out would take if the scheme was finally authorized. ${ }^{70}$ Bryant's comprehensive memorandum and sketch was submitted to Grey on 4 April 1859.

The Deputy Surveyor's suggestion was to divide the ground in squares of the Pensioners' Village so that a total of 228 building lots could be obtained. This number included the 96 existing plots, but Maclean was initially under the misconception that the 228 lots were in addition to the existing ones. The Chief Commissioner therefore proposed to the High Commissioner that about 128 plots be sold which could realize nearly $f 2000$. Maclean presumed that the 100 remaining lots would be allotted to the pensioners. From these plots a suitable endowment for the Hospital could likewise be provided. ${ }^{71}$ In his reply, Grey instructed Col Maclean that " ... a large and good reserve of lots of an endowment for the Hospital ..."72 should be made, apart from the additional plots to be allocated to some of the pensioners. The remainder might then be sold. Sir George Grey finally asked for a list and plan of the Hospital endowment lots, but left the exact number to Maclean's discretion.

Maclean immediately acted on the High Commissioner's instructions. In a letter of 20 April 1859 to Grey, he suggested that 56 cottages in the existing Pensioners' Village be allocated for the Hospital endowment as well as 100 building lots in the proposed extension. ${ }^{73}$ This was with the understanding that those of the cottages in the original Village which would be required for public offices, would be used as such, either gratuitously or at a nominal rent. ${ }^{74} \mathrm{~A}$ few months later the High Commissioner requested Col Maclean to take immediate steps to have the grants for the Hospital endowment drawn up. Grey further instructed that six lots in the Pensioners' Village and six in the new part be reserved as endowments for the African School. ${ }^{75}$

The Chief Commissioner accordingly instructed Bryant to take the matter further. He then for the first time realized that the correspondence between Grey and Maclean had been based on a misunderstanding as to the number of available additional lots. Bryant also remarked that apart from 26 pensioners who were entitled to additional lots, a Mr Harmann had been authorized to receive four plots. If the original intention to reserve one hundred erven for endowment purposes was carried out, it only left two to sell by auction. ${ }^{76}$ On Bryant's enquiry Maclean confirmed on 15 August 1859 that his proposed allocation of building lots remained unchanged. ${ }^{77}$

A special surveyor was then appointed to complete the subdivision of the Pensioners' Village extension at a rate of $f 1$ per lot. ${ }^{78}$ The surveying and a definition of the plots were finally completed early in December 1859. It was at that stage that Bryant pointed the additional plots out to the pensioners concerned, as had been mentioned earlier.

At that stage it became evident that there was a final number of 238 plots in the enlarged Village, which were 10 plots more than Bryant had originally proposed. The Assistant- Surveyor General summarized the existing position in December 1859. He mentioned that 45 of the 50 cottages earmarked for the Hospital endowment in the original Pensioners' Village were occupied. The 100 additional lots allocated for this purpose were still vacant ground. ${ }^{79}$ The

70 BK 386: Maclean - Bryant, 17.12.1858, p 18

71 BK 380: Maclean - Grey, Schedule 31, 4.4.1859

72 BK 380: Maclean - Grey, Schedule 31, 4.4.1859, containing Grey's undated reply.

73 Maclean simultaneously suggested that the number of pensioners' cottages in the original part of the

Village be limited to forty.

74 BK 373: Maclean - F Travers (Secretary to Grey), 20.4.1859, p 276

75 GH 30/5: F Travers (Secretary to Grey) - Maclean, 23.7.1859

76 BK 18: Bryant - Maclean, 10.8.1859

77 BK 386: Maclean - Bryant, 15.8.1859, p 352

78 BK 408: Maclean - Bryant, 15.11.1859, p 40 (The surveyor was a Mr McDonald)

79 BK 3: Bryant - Maclean, 14.12.1859 
figures for the African School endowment showed that 3 of the 6 cottages in the original part of the Pensioners' Village were occupied, with the additional plots in the extended section also still being vacant land. Bryant added that all of the 40 cottages reserved for pensioners had been occupied and that 27 additional plots had eventually been allocated for this purpose. In addition to the four plots which Harmann received, this accounted for a total number of 225 plots, which left 132 allotments for Government use. ${ }^{80}$ Maclean remarked on 16 December that he was not yet prepared to give any instructions respecting the disposal of the School endowments or of the 13 remaining plots. ${ }^{81} \mathrm{~A}$ special local trust fund had to be opened for the Hospital endowment. The High Commissioner subsequently gave instructions in February 1861 that the rentals from the School endowment properties should be remitted at a quarterly of half-yearly intervals to the Bishop of Cape Town. ${ }^{82}$

\section{CONCLUSION}

By 1861 the administration and control of the original Pensioners' Village and its extension were on a properly organized footing. Although this area was still to be known for many decades as the Pensioners' Village, the system of granting cottages to pensioners was discontinued early in $1861 .{ }^{83}$ Many of the pensioners had by then already bought and built their own houses in the German Village. All this meant the end of an era for the Pensioners' Village and also eventually the disappearance of the military pensioners as a distinctive part of King William's Town's population. The importance of this integral part of the Kaffrarian capital can however, also for the church, hardly be over-estimated. It provided much-needed accommodation to immigrants, the sick, the military and other groups at a crucial time in the town's expansion. The extension of the Village further not only played a part in the growth of the town and the spiritual well-being of its people, but also assisted through the Hospital and School endowments in the material well-being of these institutions. The original part of the Pensioners' Village was probably the first group housing scheme ever to be undertaken on such a large scale in South Africa. ${ }^{84}$ All of this also had its ecclesiastical implications, which will be discussed in the next article with its specific focus on the expansion of missionary work in this context. The eventual civilizing influence of the church at social, economic, educational and cultural levels in this area was indeed remarkable.

\section{ABBREVIATIONS:}

BK: British Kaffrarian Records

CO: Colonial Office Records

GH: Government House Records

G Journal: Graham's Town Journal

K Gazette: King William's Town Gazette and Border Intelligencer

LG: Lieutenant-Governor's Records

PRIMARY SOURCES CONSULTED

\section{Cape Archives}

British Kaffrarian Records (BK)

80 BK 3: Bryant - Maclean, 14.12.1859

81 BK 408: Maclean - Bryant, 16.12.1859, p 79

82 BK 387: Brownlow - Taylor, 14.2.1861. p 59

83 BK 409: Brownlow - Patrick Dowell, 17.2.1861, p 51

84 Because it was a Government scheme, the planning and erection of the cottages in the original part of the

Pensioners' Village were extremely well documented. 
BK 1-5: Letters received, High Commissioner, 1847-1863

BK 17-20: Surveyor General, King William's Town, 1853-1861

BK 57: Sundry Memorials, 1854-1866

BK 93-94: Civil Engineer, 1855-1866

BK 371-373: Letters Despatched to High Commissioner, 1848-1863

BK 374-382: Schedules of Documents submitted to the High Commissioner, 1852-1863

BK 386-387: Letter Books, 1858-1862

BK 403-409: Miscellaneous Letter Book, Letters Despatched, 1847-1862

Colonial Office (CO)

CO 634: Chief Commissioner, British Kaffraria and Special Commissioner, Sir G Clarke

Government House (GH)

GH 8/49-50: British Kaffraria, Demi-Official, 1854-1858

GH 30/4-5: Letter Books, British Kaffraria, 1852-1860

GH 36/1-4: Military Secretary's Office, Military and Naval, 1855-1861

Maps and Plans (M1)

\section{Kaffrarian Museum}

Diary of Dr JP Fitz Gerald, 1856-1859

Miscellaneous Maps, Plans and Portraits

\section{Newspapers}

The Graham's Town Journal, March 1853-August 1856

The King William's Town Gazette and Border Intelligencer, August 1856-October 1861

\section{SECONDARY SOURCES CONSULTED}

Bateman, JA 1959. Grey Hospital, King William's Town, a Hundred Years of Medical Service. East London. Bateman, JA 1961. The Borough of King William's Town. A century of Service. King William's Town.

Boyden, PB, Guy, AJ \& Harding, M 1999. Ashes and Blood: The British Army in South Africa 1795-1914. Imperial Army Museum, London.

Brownlee, Frank (compiler) 1923. The Transkeian Native Territories: Historical Records. Alice.

Bundy, C 1979. The Rise and Fall of the South African Peasantry. London

Butler, WF 1899. The Life of Sir George Pomeroy-Colley. London.

Callaway, G. Pioneers in Pondoland. Lovedale (n.d.).

Crais, CC 1992. The Making of the Colonial Order: White Supremacy and Black Resistance in the Eastern Cape (1770-1865). Johannesburg

Dowsley, E 1932. An Investigation into the Circumstances relating to the Cattle-killing Delusion in Kaffraria 1856-1857. Unpublished MA thesis, Unisa.

Giliomee, H \& Mbenga, B 2007. Nuwe Geskiedenis van Suid-Afrika. Kaapstad

Gordon-Brown, A. 1979. The Settlers Press: Seventy years of printing in Grahamstown (1830-1900) covering the publication of books, pamphlets, directories, almanacs and newspapers with historical notes, anecdotes and contemporary illustrations. Cape Town.

Le Cordeur, BA 1959. Robert Godlonton as Architect of Frontier Opinion(1850-1857). Archives Yearbook for South African History II. Cape Town.

Milton, J 1983. The Edges of War: A History of Frontier Wars (1702-1878). Cape Town.

Moodie, D (compiler and editor) 1960. The Record: A Series of Official Papers Relative to the Condition and Treatment of the Native Tribes of South Africa. Cape Town. (Photostatic reprint).

Peires, JB 1981. The House of Phalo: A History of the Xhosa People on the Days of their Independence. Johannesburg 
Rutherford, J 1961. Sir George Grey KCB, 1812-1898. A study in Colonial Government. London. Theal, GM 1964. History of South Africa, Volume IV (1795-1872) Facs Ed, Cape Town.

\section{KEY WORDS}

Frontier Capital

Pensioners' Village

King William's Town

Governor George Grey

Dr JP Fitz Gerald

Expansion of Christianity

\section{TREFWOORDE}

Grensgebied-hoofstad

Pensionarisse-dorp

King William's Town

Goewerneur George Grey

Dr JP Fitz Gerald

Uitbreiding van die Christendom

Prof JW(Hoffie) Hofmeyr

Dept Ekklesiologie

Universiteit Vrystaat

Posbus 339,

Bloemfontein,

9300

E-pos: linhof@mweb.co.za 